\title{
Military Field Camp Installation Improvement Solutions: Lithuania Case
}

\author{
Svajone BEKESIENE ${ }^{1}$, Andrejus KRIVCOVAS ${ }^{2}$ \\ ${ }^{1,2}$ General Jonas Žemaitis Miltitary Academy of Lithuania, Silo str. 5A, LT-10322 Vilnius \\ E-mails: ${ }^{1}$ svajone.bekesienel@lka.lt
}

\begin{abstract}
The installation plan, operation and functions of the military field camp are very important for a military unit action. Every army in a NATO country strives to set up a military camp that is as flexible and comfortable as possible. NATO has set standards for the installation of a military field camp, and each country in the organization relies on this standard. This study was focused on how to build a military field camp as quickly as possible and to minimize the loss of various resources.

The research developed a focus group survey analysis method to identify weaknesses in the military field camp setting process, accomplished an in-depth interview analysis method with four Lithuanian Grand Duke Vytenis General Support Logistics Battalion Field Camp Installation Experts. Moreover, was accomplished a comparative analysis to compare military field camps plans before and after installation. In addition, an operational process analysis approach was used, which depicts the installation of a military field camp from planning to unit deployment. There was used the Bizagi Modeler v3.7 software to construct the intelligent process automation diagram which showed the military camp installation improvement solutions [18]. Moreover, the in-deep cause analysis method was used, which helped to identify the main problems of the military field camp installation.
\end{abstract}

KEY WORDS: military field camp; resources; military field camp installation; Lithuanian Grand Duke Vytenis Logistics Battalion

\section{Introduction}

The installation plan, operation and functions of the military field camp are very important in a military unit operation. Each NATO countries' army strives to set up a military camp that can be as flexible and comfortable as possible. NATO has set standards for the installation of a military field camp, and each country in the organization relies on this standard. Location, weather, seasons determine the specifics of the camp installation, and the installation of camp facilities and premises, the selection of their location is very important for the quality of all activities and operations in the camp area. In order to build a military field camp as quickly as possible and to minimize the loss of various resources when setting up a military field camp, it is important to understand the specifics of setting up a military field camp [10].

The Military Field Camp is described as a place where soldiers live, eat, sleep, work, train and rest. There are three types of outdoor camps:

- Patrol Base [1],

- Operational Camp (up to 80 days) [2],

- Long-term camp - battalion-sized units are located there.

The Military Field Camp has a logistical function, which consists of operating, storing various supplies such as: food, water, ammunition, medical supplies, etc. The size of the field camp to be set up depends on the type (number of troops and duties) of the troop unit there. The size depends on how many tents there will be, and the purpose of the unit depends on how much and what equipment the unit needs to carry and store [8]. Military camps are usually set up in the case of long-term (weekly and more) military exercises. Military outdoor camps must be equipped with roads, canteen, accommodation, showers, washrooms, work areas, warehouses, laundries, helicopter parking, communications center, medical aid station, vehicle parking and repair shops, fuel depots, medical station, morgue (in the case of war), fire-fighting rooms containing various means of extinguishing a fire.

Observation towers and bunkers are very often built in the camp for security reasons. Turret troops on standby can see the danger, and resting soldiers could hide in the bunkers from artillery attacks or any similar life threat. All hazardous materials and equipment must be stored and stored indoors away from the living and medical facility. There

\footnotetext{
${ }^{1}$ Corresponding author.

E-mail address: svajone.bekesiene@1ka.lt
} 
are also toilets and rooms where soldiers eat (canteens), study or work. Warehouses shall be constructed in such a way that vehicles can be approached and unloaded or loaded as easily and simply as possible [1].

Logistics is improving every year in civilian companies and the military. A special role in modern logistics is played by effective decisions made by the person responsible for the logistical functions of their activities. Effective decisions are made individually and in groups, using a variety of logistical analysis functions. In military field camps, in order for the various equipment to be operated properly and economically, without wasting resources, the actions and decisions to be taken by the equipment operation planner must be properly considered [9]. Logistics management must ensure constant control of the economy, that is, compare price and quality.

Since 2015, the number of field exercises has increased significantly due to the commencement of the call to the Lithuanian Armed Forces. As the exercise increased, there was a great need for military field camps. Improperly equipped military field camps can take into account the comfort, health and motivation of soldiers to perform assigned tasks. For this research under investigation was the IRON WOLF 2019 military field camp in Švenčionèliai, the processes and activities of the Lithuanian Grand Duke Vytenis General Support Logistics Battalion for setting up a military field camp. The aim of the research is to identify the main problem of the military field camp and to provide solutions for the military field camp installation.

\section{Study Design}

Problems in the installation of a military outdoor camp arise from the planning of the installation of the outdoor camp to the establishment of the unit. Five different research methods: a focus group survey analysis, indepth interview analysis, a comparative analysis, activities process analysis and in-deep cause analysis method, were performed to identify and solve the problems.

Specialists of Vytenis General Support Logistics Battalion holding different military positions related to the setting up of a military outdoor camp were interviewed using the in-depth interview method. This study sought to identify problems during installation and planning. An in-depth interview was built as a normal conversation, as natural flow with one question leading to the next. The exact questions were selected and structured. The questions were designed on the basis of military camp installation process requirements and problems such as what is missing when setting up an outdoor camp and what problems are most often encountered by outdoor camps. This study was conducted in accordance with ethical requirements. Consequently, the in-depth interview was structured as a process of building trust. The study began with easier background questions and finally ended with a summary and closure on a good note.

The comparative analysis was applied to study the NATO standards, hygiene norms and the original and corrected plans of the military field camp. The comparisons were made between the military field camp which was installed in the Švenčionèliai district for Ironwolf 2019 training and the prepared initial plan of the installed field camp. This method was chosen to identify the disadvantages and advantages of setting up a military outdoor camp.

The method of operational process analysis was used to create process diagrams. Diagrams that show how the process is going at the moment, with existing problems, and how the process will go after those problems are analysed and eliminated. The diagrams were drawn using the Bizagi Modeler v3.7 software as intelligent process automation [18]. Constructed diagrams helped to show the installation of a military field camp, from the planning of the field camp to the establishment in the field camp.

The method of deep cause analysis was useful for creating cause and effect diagrams. Based on this method, emerging problems were identified and grouped. The results of the study are presented in a "fish bone" diagram.

After performing all the selected research methods, solutions to the main problem were proposed.

\section{Results and Discussions}

The investigations completed in the military field camp which was installed in the Švenčionèliai district for Ironwolf 2019 training demonstrated that the military camp must be equipped with all the necessary equipment and materials which have to enable soldiers to plan operations, live and rest. Various civilian companies hired in the military field camp perform the functions assigned to them, which improve the infrastructure of the camp and improve life in it.

Following the choice of analytical methods, the main problem with the installation of the Military Field Camp (MFC) was identified - the inadequate setting up of the Military Field Camp. The main causes of the problem were:

- Modifying the military field camp plan;

- Lack of cooperation between departments;

- Untested equipment prior to setting up a military field camp;

- Military field camps are not set up on a regular basis;

- Insufficient human resources to set up an outdoor camp;

- Shortage of specialists;

- Insufficient transport. 
The solution for each problem affects the installation of a military field camp. The amount and possibilities of resource use, the time of installation of an outdoor camp affect the installation of the MFC. Each solution presented in this article is reasonable and can improve the installation of the MFC.

Solving working method problems will help to use less resources and reduce various shortcomings. Solving human factors will reduce military equipment failures in the logistics battalion and reduce the time it takes to set up a military field camp. Eliminating resource problems will reduce the use of financial resources, the time to set up a military field camp, and the time to repair and install equipment. The eliminated problems will increase the efficiency, quality and reduce the installation time of the MFC installation.

\subsection{Comparative Data Analysis Outcomes}

Comparative data analysis was used to compare the original military field camp plan's details with the established field camp plan. The aim of the study was to identify changes, problems, and causes in a military camp installation. The camp, the original and factual plans of which was being compared, was built in Švenčionèliai district for the "Ironwolf 2019" exercise. This military camp was built by 300 troops according to the second tier of NATO STANAG standards.

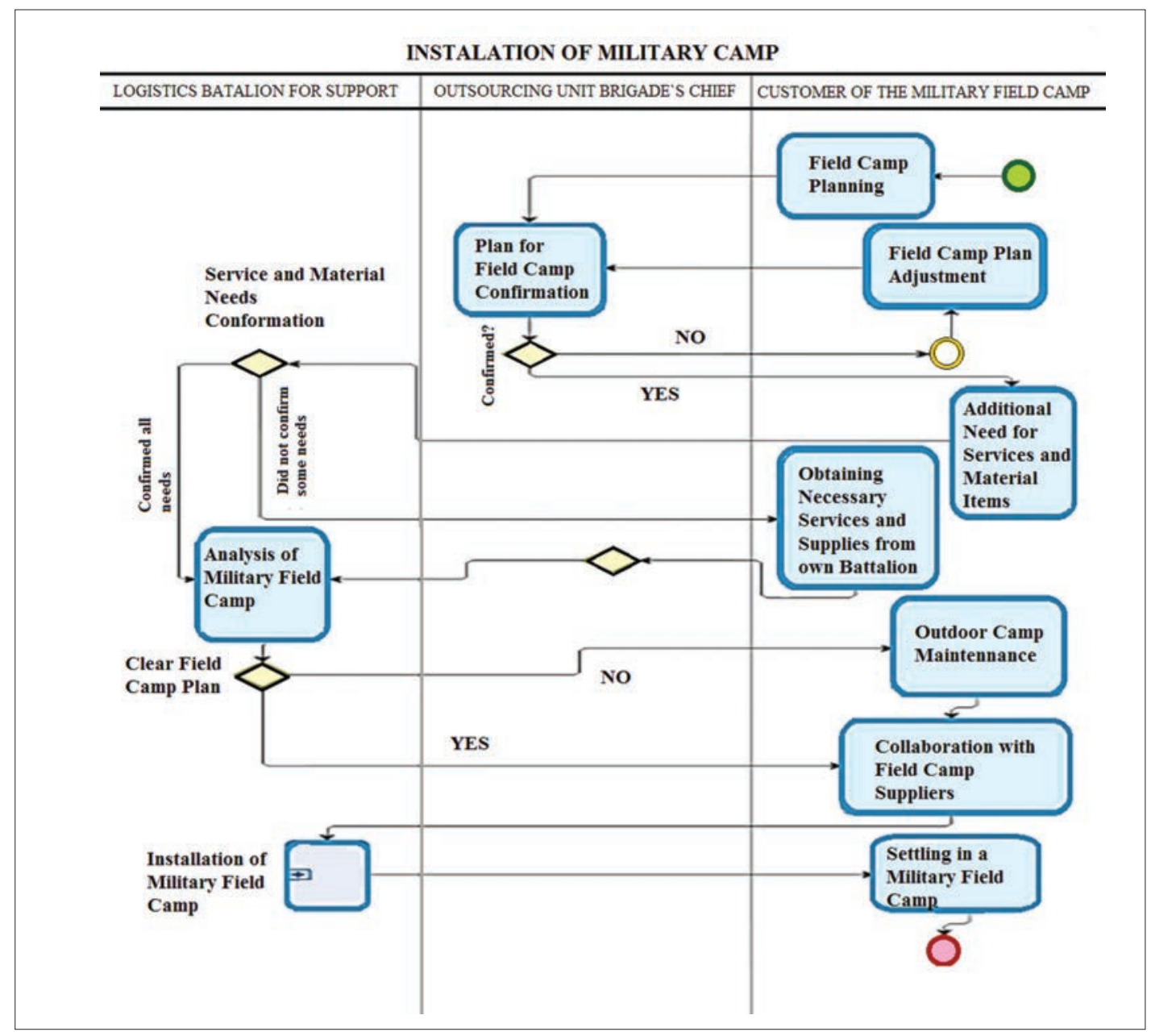

Fig. 1. Schematic view of the processes' sequence for setting up a military field camp after the deficiencies have been rectified. Source: authors.

Military camp planning begins with performing reconnaissance, which includes site reconnaissance and infrastructure site selection. If the site is in line with the plan, the plan is approved and further action begins. If the plan does not comply with the site, then it is amended to meet the requirements of hygiene standards and the site.

After the approval of the final plan, the process of preparation is started, and a lot have to prepared: material items, vehicles, special equipment, and additionally have to be ordered various required services. All these works are carried out at the same time and after the transfer of all the infrastructure to the site of the outdoor camp.

After the installation of the outdoor military camp, the establishment of the unit takes place in it. When the 
military unit is located in an outdoor camp, deficiencies such as equipment failure or the need for certain pieces of equipment or infrastructure from the ordering unit usually occur. All these shortcomings could be avoided by the cooperation between the units during the installation of the outdoor camp. In the event of deficiencies, additional resources (fuel, time, human, financial) are used, which are used to eliminate the deficiencies, if the deficiencies are not rectified within one day, they are tried to be remedied until all parts of the infrastructure are working well. After eliminating the shortcomings in the military camp, it can be state that the installation of the camp is complete.

The comparative data analysis showed that three days after the establishment of the military field camp, the original plan, which was drawn up before the establishment of the camp, did not provide for a large number of infrastructure premises and, as a result, some changes had to be made during the establishment of the camp.

Reconnaissance of the territory and collection of information is also very important part of camp planning [16]. After the reconnaissance, soldiers can minimally change the plan of the military field camp and then prepare transport, equipment, and various material items. By changing some parts of the plan, there is no cooperation between the units, which leads to shortcomings in the installation of the military field camp and additional requests from the customer to improve the military field camp.

Cooperation is one of the most important things, because it can lead to unanimous solutions and avoid most losses. Based on the analysis of the focus group survey the reasons why the plan changes significantly when starting to set up a military field camp were identified. The cooperation between the logistics battalion and other units that have ordered the installation of a military field camp can be identified as one of the problems' reason.

Lack of human resources is another existing problem why the outdoor camp was not fully equipped during installation. The lack of certain specialists and the ordering of certain specialist services during installation consumed time resources, so some elements of the infrastructure were not installed at a certain time.

The diagram in Figure 1 was drawn by Bizagi Modeler v3.7 software [18] and shows the installation of the MFC from the beginning of planning to the establishment of the unit in the Military Field Camp. This scheme illustrates additional workarounds that can be avoided. The establishment of a military field camp begins with the planning of the field camp and ends with the establishment of the unit in the equipped field camp. This diagram shows how the whole process of setting up an outdoor camp should go without any flaws.

\subsection{In-deep Cause Method Analysis Results}

The in-deep cause analysis method of the problems of the military field camp installation helped to reveal the four main problems that arise during the installation work. Given the nature of the problem, these four groups were identified as: Work Methods, non-compliance with NATO standards by military field camps (Disobey NATO Standards), Resources, and Human Factors (Fig. 2).

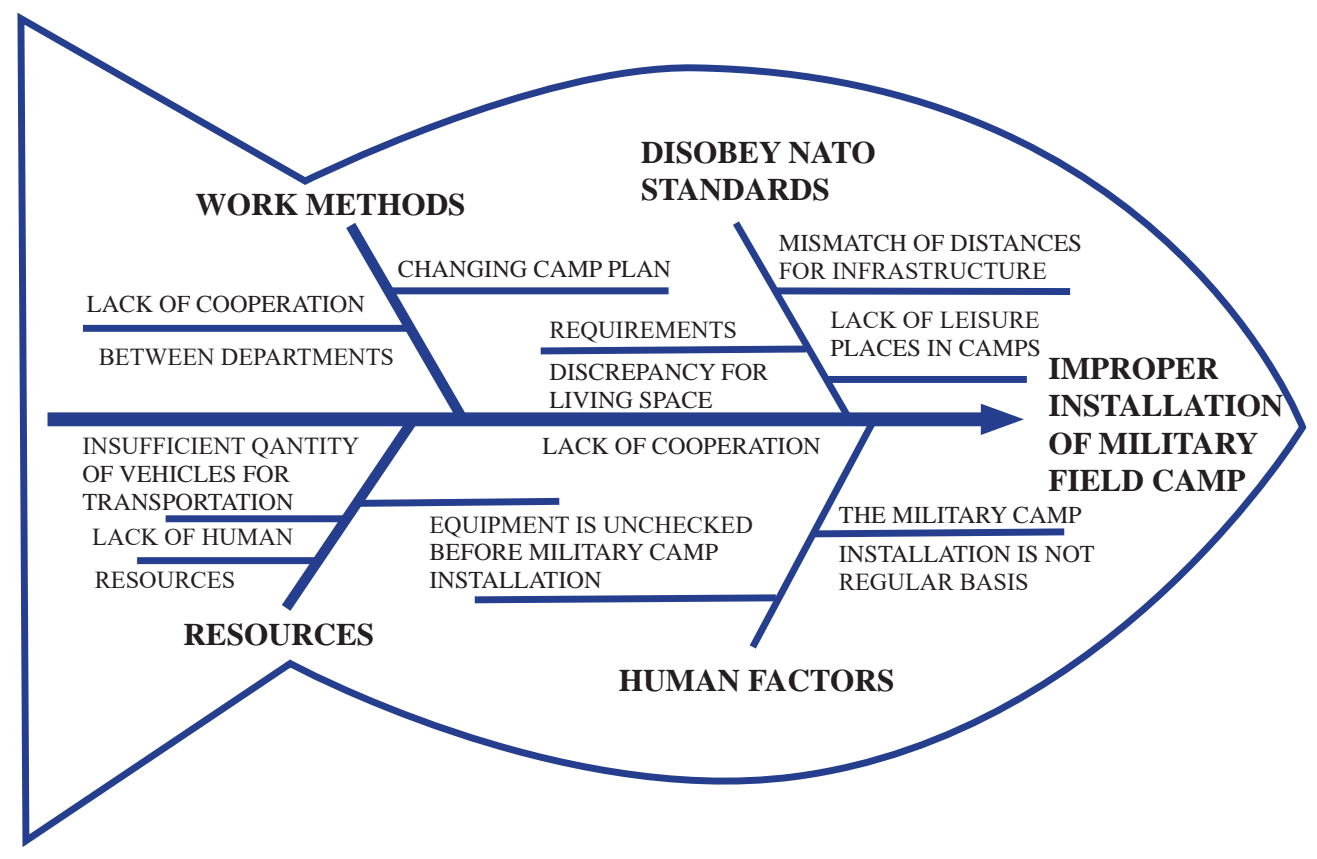

Fig. 2. Fish bone diagram for in-deep cause analysis. Source: authors. 
The in-deep cause analysis focused on additional identification of the main problems which appear in each of these four groups solely. The identified reasons for each of the four problems can be presented in details as follows: I. Work Methods:

- Changing the plan of a military field camp;

- Lack of cooperation between departments.

II. Resources:

- Insufficient amount of equipment;

- Insufficient human resources for setting up an outdoor camp;

- Insufficient transport;

- Lack of specialists.

III. Human Factors:

- Equipment not checked before setting up a military field camp;

- Failure to comply with the established military field camp plan;

- The installation of a military field camp is not carried out at a constant time.

IV. Non-compliance with NATO standards in military field camps:

- Requirements for NATO living standards;

- No leisure facilities are being built in the military outdoor camp;

- Non-compliance of the infrastructure installation distance with NATO standards.

There were identified four problems groups, but the main study focus was on three problems groups: Work Methods, Resources, and Human Factors. The Group for Non-Compliance with NATO Field Camp Standards for Military Field Camps was not under investigation because it does not allow to make any changes. Furthermore, it is not mandatory to rely on NATO standards, but it is recommended, so there are places in the military field camp that do not meet NATO standards and take up more space in the camp area. In this case, we are talking about living accommodations (tents).

The detailed analysis results are presented below in the sections 3.2.1, 3.2.2 and 3.2.3.

\subsubsection{Military Field Camp Work Methods Organization Guidelines}

In Švenčionèliai district, a military outdoor camp was planned to be established within 3 working days. During these working days, showers, toilets, a canteen, living quarters, a headquarters and a parking lot had to be provided. However, a lot of changes had to be made during the installation and after the military field camp was already installed. These changes required the use of additional resources. Soldiers additionally had to go to the military field camp to rectify the deficiencies, soldiers were transported by vehicles that used additional fuel $[11-15,17]$. In the military field camp where the soldiers were stationed, the exercise could not be carried out because the infrastructure in the field camp was being rebuilt. Additional problems with the installation of the military field camp stemmed from the fact that the prepared plan was not followed. Furthermore, after its installation, there were made more additional changes.

Table 1.

Improper work methods' causes, damages, and problem-solving

\begin{tabular}{|c|c|c|}
\hline \multicolumn{3}{|c|}{ WORK METHODS } \\
\hline Causes & Damages & Decisions \\
\hline $\begin{array}{l}\text { 1.Changing the plan of } \\
\text { a military field camp. }\end{array}$ & $\begin{array}{l}\text { When changing the outdoor camp } \\
\text { plan during installation, unforeseen } \\
\text { additional resources are used. } \\
\text { - Reconstruction of the military field } \\
\text { camp infrastructure. }\end{array}$ & $\begin{array}{l}\text { There must be a discussion of the military } \\
\text { field camp plan between the two units as } \\
\text { it is drawn up and adjusted. }\end{array}$ \\
\hline $\begin{array}{l}\text { 2. Lack of cooperation } \\
\text { between departments. }\end{array}$ & $\begin{array}{l}\text { Use of additional resources } \\
\text { to rebuild military field camp } \\
\text { infrastructure. } \\
\text { Deficiencies after the installation of } \\
\text { a military outdoor camp. }\end{array}$ & $\begin{array}{l}\text { - Both units have to conduct discussions on } \\
\text { the military field camp plan together. } \\
\text { Both units have to carry out the } \\
\text { reconnaissance process of the military } \\
\text { field camp together. } \\
\text { Logistics battalion and customer must } \\
\text { cooperate throughout the installation of the } \\
\text { military field camp. }\end{array}$ \\
\hline
\end{tabular}

Source: authors. 
Creating the plan for a military field camp is one of the first steps before setting up the camp. Once the location has been surveyed, the plan for the outdoor camp may still be changed, but it is not advisable to make the changes in the plan when the military outdoor camp installation is in progress. The study has proved that the drawing up a plan before setting up an outdoor camp after a reconnaissance must be final to ensure that the military outdoor camp will be set up within the allotted time without various changes and additional problems. The military field camp working methods organization guidelines are presented in the Table 1.

\subsubsection{Military Field Camp Resources Management Guidelines}

Lack of resources is the most common problem in setting up a military field camp. When planning the installation of a military field camp, the resources are usually allocated in such an amount that it is sufficient only for the installation and partial arrangement of the military field camp. The resulting shortcomings often lead to higher resource utilization, necessitating a recalculation of everything. The details of research investigation results for military field camp resources management guidelines are presented in Table 2.

The services of civilian companies could be used to address resource scarceness. Ordering equipment transportation services could solve the problem of lack of vehicles in the logistics battalion. With more vehicles, equipment would move faster and resources would be saved.

Table 2.

Resource group causes, damages, and problem solving

\begin{tabular}{|l|l|l|}
\hline \multicolumn{1}{|c|}{ Causes } & \multicolumn{1}{c|}{ RESOURCES } \\
\hline $\begin{array}{l}\text { 1. Insufficient transport } \\
\text { quantity in the Logistics } \\
\text { Battalion. }\end{array}$ & Exploitation of fuel and time resources. & $\begin{array}{l}\text { Repairing existing vehicles. } \\
\text { Use trucks rent from civilian } \\
\text { companies. }\end{array}$ \\
\hline $\begin{array}{l}\text { 2. Lack of human resources } \\
\text { in the Logistic Battalion. }\end{array}$ & $\begin{array}{l}\text { The installation time of the military } \\
\text { field camp is increasing. }\end{array}$ & $\begin{array}{l}\text { Attracting and recruiting soldiers to } \\
\text { serve in the Logistics Battalion. }\end{array}$ \\
\hline $\begin{array}{l}\text { 3. Lack of specialists' } \\
\text { resources in the Logistic } \\
\text { Battalion. }\end{array}$ & $\begin{array}{l}\text { Providing sanitation services is not } \\
\text { efficient. } \\
\text { The install of special equipment in the } \\
\text { military field camp takes too long time. }\end{array}$ & $\begin{array}{l}\text { Sending existing troops from the } \\
\text { Logistics Battalion to specialist training } \\
\text { courses. } \\
\text { Finding specialists in the army and } \\
\text { attracting them to serve in the Logistics } \\
\text { Battalion. }\end{array}$ \\
\hline
\end{tabular}

Source: authors.

Since 2015, the number of military trainings in infantry battalions has increased, which has created a great need to set up military outdoor camps. The amount of new equipment in the logistics battalion increased, the need for military field camps increased, but the number of soldiers in the logistics battalion remained almost the same as in 2015. This lack of human resources problem can be solved with attracting and recruiting soldiers to serve in the Logistics Battalion.

\subsubsection{Identified Human Factor Problems during the Establishment of a Military Camp}

The conducted study helped to identify the human factor problems which appear during the establishment of a military camp. In Table 3 are presented all identified causes, damages and problem-solving possibilities. 
Guidelines for solving human factor problems during the establishment of a military camp

\begin{tabular}{|l|l|l|}
\hline \multicolumn{1}{|c|}{ Causes } & \multicolumn{1}{c|}{ HUMAN FACTOR } \\
\hline $\begin{array}{l}\text { 1. Equipment not checked } \\
\text { before setting up a military } \\
\text { field camp. }\end{array}$ & $\bullet \begin{array}{l}\text { Equipment failure, which takes } \\
\text { time to set up a military field camp. }\end{array}$ & $\begin{array}{l}\text { Decisions } \\
\text { Equipment must be inspected } \\
\text { before a new military field camp is } \\
\text { installed. } \\
\text { Check the operation of the } \\
\text { equipment regularly. }\end{array}$ \\
\hline $\begin{array}{l}\text { 2. The installation of a } \\
\text { military field camp is not } \\
\text { carried out consistently. }\end{array}$ & $\begin{array}{l}\text { Increased use of financial } \\
\text { resources. } \\
\text { The time for setting up a military } \\
\text { field camp is lengthening. }\end{array}$ & $\begin{array}{l}\text { Each soldier must be trained to } \\
\text { work and repair the equipment } \\
\text { assigned to him. } \\
\text { Purchase of special equipment. }\end{array}$ \\
\hline
\end{tabular}

Source: authors.

Based on the results of the in-depth interview study, it can be argued that equipment failure is often caused by the human factor. The equipment is the important part of the military camp. So, it must be inspected both externally and internally, and not only after the outdoor camp but also before the camp is set up. Moreover, all electrical wiring, batteries, and other devices that support the operation of the equipment have to be inspected. Improper equipment or equipment failure takes extra time to set up a military camp.

Due to the lack of equipment, the logistics battalion hires civilian companies or rents their equipment. Based on in-depth analysis, civilian company employees often slow down the time of setting up an outdoor camp for their own personal reasons. Often, the time to set up an outdoor camp is slowed down due to the soldiers' ignorance or unfamiliarity with the equipment assigned to their work. Due to these problems, the process of setting up a military field camp is slower.

It takes time and effort to solve the all causes. After solving all mentioned problems, the installation of a military field camp can be possibly making more efficient and faster. Additionally, the use of resources to set up a military outdoor camp will be reduced, leading to savings in financial resources that can be used for a variety of purposes, such as: upgrading equipment and transport, purchasing new equipment and transport.

\section{Conclusions}

Military field camp plans are prearranged by the unit that orders the military field camp. Once a plan is drawn up, it is sent to the brigade commander who decides whether or not to approve this plan. After the field camp plan approvement, it is sent to the General Support Logistics Battalion, where the field camp installers familiarize themselves with the plan. Additionally, they have to begin the re-inventorying, which is an insight into where the field camp will be located. The location of each military field camp infrastructure is checked.

The plan used to set up the MFC can be minimally modified after the inspection. Basically, the Departments of the Lithuanian Armed Forces for building MFCs use NATO standards, but the commander in charge of the MFC may modify the camp plan in a manner not recommended by NATO standards.

The findings of the research revealed that in order to improve the equipment of the military field camp when ordering the field camp from the logistics battalion, each unit should maintain cooperation, transport, financial, human and time resources should be properly distributed. Moreover, each soldier must be trained how to use the equipment they are assigned. In addition, each vehicle and equipment must be inspected before being used at the military field camp site.

\section{References}

1. Raymer, J. BASE CAMPS. Washington. 2017.

2. Military Field Camp Hygiene Rules, 2002.

3. Camp Leatherneck Marine in Helmand Province, Afghanistan, 2019.

4. Neumann, V. Protection of Critical Infrastructure Component Against a Vehicle Attack. Proceedings of Transport Means 2017.

5. Smal, T. Decision Making Scenarios in Military Transport Processes in Refers to Military Security. Part 1 - 
Approach to Logistics and Transport Costs. Proceedings of Transport Means 2017.

6. Urbancová, Z. Selected Methods of Operational Analysis Usable in Evacuation of People. 2017

7. WestPoint. Base Camp Design Simulation Training. Hoult, C. Deployable Infrastructure 2028. 2011.

8. Ezell, B. Base Camp Design: Site Selection and Facility Layout. 2001.

9. Milewski, R. Cost Decision Trees in International Military Logistics. Proceedings of Transport Means 2019.

10. Dvorak, P. Energy saving in military camp. Proceedings of Transport Means 2019.

11. Hoskova-Mayerova, S.; Hubacek, M.; Bures, M.; Bekesiene, S. 2017. Vehicle movement modelling possibilities for defense and crisis management, Safety and Reliability - Theory and Applications - Epin \& Briš (Eds). London: Taylor \& Francis Group, 3035-3039.

12. Cibulová, K. 2017. The Mobility during Crisis Situations. In: Structural and Mechanical Engineering for Security and Prevention ICSMESP 2017. Switzerland: Trans Tech Publications, 236-241. ISSN 1662-9809.

13. Lopatka, M.J. 2018.Assessment of River Crossing Possibility with Existing Pontoon Bridge, Bekesiene S., Hoskova-Mayerova S. (Eds.), Challenges to National Defence in Contemporary Geopolitical Situation (CNDCGS' 2018), 25-31.

14. Rybanský, M.; Hofmann, A., Hubacek M.; et al. 2015. Modeling of Cross-Country Transport in Raster Format, Environ. Earth Sci., 74: 7049.

15. Rybanský, M.; Vala, M. 2010. Relief Impact to Cross-Country Movement, In: Proceedings of the Joint 9th AsiaPacific ISTVS Conference, Sapporo, Japan, 16 p.

16. Pincevičius, A.; et al. 2008. Modeling of Infantry Attacks on Real Terrain. Nonlinear Analysis: Modelling and Control, vol. 13(4): 491-501. ISSN 1392-5113

17. Cibulová, K.; Hejmal, Z.; Vala, M. 2015.The Influence of the Tires on the Trafficability. International Conference on Military Technologies. Brno: University of Defence, 219-222. ISBN 978-80-7231-976-3.

18. Bizagi Modeler. Available from: https:/www.bizagi.com/en/platform/modeler 